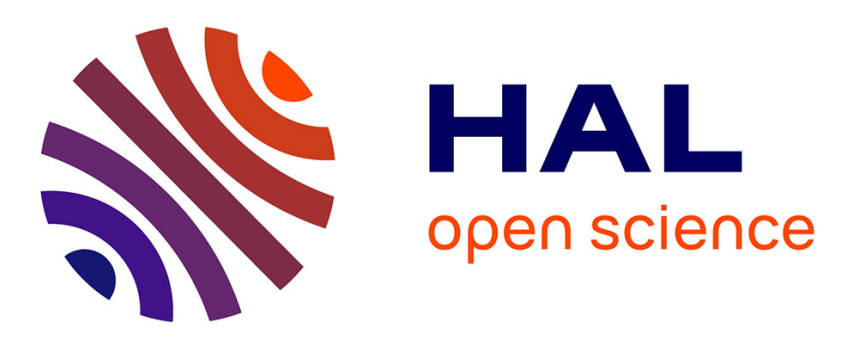

\title{
Exoskeletal deformities in Palaemonidae are they a threat to survival?
}

Mélanie Béguer, Lionel Feuillassier, Pierre Elie, Philippe Boët, Michel

Girardin

\section{- To cite this version:}

Mélanie Béguer, Lionel Feuillassier, Pierre Elie, Philippe Boët, Michel Girardin. Exoskeletal deformities in Palaemonidae are they a threat to survival?. Marine Environmental Research, 2010, 69 (3), pp.109. 10.1016/j.marenvres.2009.09.001 . hal-00565101

\section{HAL Id: hal-00565101 \\ https://hal.science/hal-00565101}

Submitted on 11 Feb 2011

HAL is a multi-disciplinary open access archive for the deposit and dissemination of scientific research documents, whether they are published or not. The documents may come from teaching and research institutions in France or abroad, or from public or private research centers.
L'archive ouverte pluridisciplinaire HAL, est destinée au dépôt et à la diffusion de documents scientifiques de niveau recherche, publiés ou non, émanant des établissements d'enseignement et de recherche français ou étrangers, des laboratoires publics ou privés. 


\section{Accepted Manuscript}

Exoskeletal deformities in Palaemonidae: are they a threat to survival?

Mélanie Béguer, Lionel Feuillassier, Pierre Elie, Philippe Boët, Michel Girardin

PII:

S0141-1136(09)00118-4

DOI:

10.1016/j.marenvres.2009.09.001

Reference:

MERE 3367

To appear in:

Marine Environmental Research

Received Date:

1 July 2009

Revised Date:

1 September 2009

Accepted Date:

2 September 2009

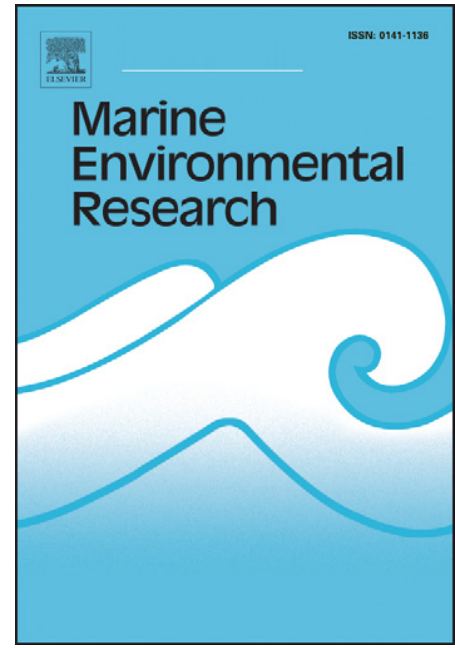

Please cite this article as: Béguer, M., Feuillassier, L., Elie, P., Boët, P., Girardin, M., Exoskeletal deformities in Palaemonidae: are they a threat to survival?, Marine Environmental Research (2009), doi: 10.1016/j.marenvres. 2009.09.001

This is a PDF file of an unedited manuscript that has been accepted for publication. As a service to our customers we are providing this early version of the manuscript. The manuscript will undergo copyediting, typesetting, and review of the resulting proof before it is published in its final form. Please note that during the production process errors may be discovered which could affect the content, and all legal disclaimers that apply to the journal pertain. 


\title{
Exoskeletal deformities in Palaemonidae: are they a threat to survival?
}

Mélanie Béguer ${ }^{\mathrm{a}, *}$, Lionel Feuillassier ${ }^{\mathrm{a}}$, Pierre Elie ${ }^{\mathrm{a}}$, Philippe Boët ${ }^{\mathrm{a}}$, Michel Girardin $^{\mathrm{a}}$

${ }^{\text {a }}$ Cemagref, Ecosema unit, 50 avenue de Verdun, 33612 Cestas, France.

* Corresponding author. Tel: +33 557892 714; fax: +33 557890801

E-mail address: melanie.beguer@cemagref.fr

\begin{abstract}
:
Shrimps of the Palaemon genus have been affected for over fifteen years by a problem of exoskeletal deformities, particularly in the Gironde estuary (France). Given the large numbers of individuals affected, this study focus on a better description of the phenomenon to estimate its impact on shrimps. This study, on P. longirostris and P. macrodactylus, is based on samples collected from 1992 to 2007 in the Gironde estuary with particular focus on the year 2007, and on a 4-month rearing of adult shrimps in experimental system. The different approaches reveal the relative persistence of the phenomenon since 1992 (with on average more than $58 \%$ of ovigerous females affected) and its persistence during shrimp life cycle, even after several moults. Important consequences associated with deformities at the individual level were demonstrated: a higher mortality, a lighter egg mass and a lower weight for a given size. The presence of exoskeletal deformities is now a major phenomenon, with profound effects on individual shrimps, and which may in turn have an important impact on the survival of the Palaemon longirostris population in particular.
\end{abstract}

Key words: Exoskeletal deformities; Palaemon spp; Gironde estuary; Estuary; Mortality; Disease; Contamination; Rearing; Decapoda 


\section{Introduction}

Exoskeletal deformity is a major phenomenon that has affected some shrimp of the Palaemon genus (P. longirostris, P. macrodactylus and P. serratus) for over 15 years (Béguer et al., 2008). This phenomenon has recently been observed and briefly described for Palaemon genus shrimp populations in the Gironde estuary, but it also affects, although to a lesser degree, shrimp in other French and European estuaries, especially the Scheldt (Belgium) and the Rhine (Rotterdam, Netherlands) (Béguer et al., 2008). In 2006, on average, over $40 \%$ of shrimp observed in the Gironde population were suffering from deformities (Béguer et al., 2008). Such a phenomenon, affecting a very large proportion of individuals from wild populations, has never been described before. Indeed, although morphological anomalies remain a very well-known and a common occurrence among crustaceans (Aguirre and Hendrickx, 2005; De Grave and Mentlak, 2008; Delphy, 1921; Dutt and Ravindranath, 1974), they are usually observed in isolated individuals or sometimes in farm rearing.

In the Gironde estuary shrimps, and particularly in $P$, longirostris and $P$. macrodactylus, these deformities are mainly in the cephalothorax, which appears either wrinkled or bent instead of being smooth and straight. The rostrum is also often partly affected: either bent to one side, or pointing downwards. Some often spectacular dissymmetries, caused by scaphocerite or uropod hypertrophy, have also been described for both species (Béguer et al. 2008).

P. longirostris is the most common and abundant shrimp in the Gironde estuary (Aurousseau, 1984; Girardin et al., 2008; Sorbe, 1983). It is a typical estuary species, completing its entire life cycle in this environment (Campbell and Jones, 1989; Gonzalez-Ortegon and Cuesta, 2006; Gurney, 1923). It is fished commercially in the Gironde estuary in large quantities using traditional methods and every year, for over a century, between 27 and 82 tonnes have been fished and consumed (Girardin et al., 2008; Holthuis, 1980). Shrimps are also an important link in the food web in this estuary, since they are prey for many species of exploited fish, like the bass or the meagre (Pasquaud, 2006; Pasquaud et al., 2008). P. longirostris has been monitored via monthly faunal surveys in the Gironde since 1978 (Girardin et al., 2008) and today its numbers seem to be in decline compared with the abundant quantities observed at the beginning of the monitoring period. 
Deformities first appeared in P. longirostris before 1992 (oldest preserved samples), but after the beginning of the 1980s, since neither Sorbe (1983) nor Aurousseau (1984) observed this phenomenon during their studies. Deformities have also been observed in P. macrodactylus, an exotic species that has colonised the Gironde estuary for about a decade (Béguer et al., 2007) and which is now found here very frequently. This invasive species is very similar to the native species, $P$. longirostris, both in its morphology and its ecology, especially its feeding habits (Sitts and Knight, 1979; Sorbe, 1983).

The causes of the deformities so far remain unknown, although recent studies seem to dismiss microorganisms, viruses or bacteria as a possible origin, and also parasites (Béguer, unpublished data). Some serious hypotheses regarding the action of organic or other types of micropollutant have since been suggested. Given the scale of this phenomenon, its impact both at the level of the individual and of the population could be considerable, and it needs to be assessed.

The aim of the present study is two-fold: (i) to provide a better description of the phenomenon of exoskeletal deformity on the basis of recent samples from the Gironde estuary (2007) and others collected since 1992, and (ii) to assess its consequences by observing individuals kept in captivity for several months, in a controlled environment.

\section{Materials and methods}

The part of the study based on preserved samples deals with $P$. longirostris and $P$. macrodactylus, the two species most frequently found. However, as P. longirostris is present in greater numbers and has similar deformities as $P$. macrodactylus, detailed results are presented for this species only. The experimental part (rearing) deals exclusively with $P$. longirostris, a species that is easier to harvest in sufficient numbers and for which there was already a methodological basis for rearing them (Aurousseau, 1984).

\subsection{Strategy to demonstrate the progress and scale of the phenomenon}

Since 1979, a large part of the estuary had been sampled monthly for fauna survey (mainly fishes and crustaceans, Girardin et al., 2008) (Fig 1). The protocol for these campaigns is described in Béguer et al (2007). Temperature and salinity were recorded at each station. Shrimp samples from each of these campaigns have been preserved since 1992. To assess the 
scale of the deformity phenomenon and its evolution over the years, sub-samples were observed. For every year until 2007, about thirty ovigerous $P$. longirostris shrimps collected from the upstream part of the estuary during May or June, depending on abundance, were measured and examined. Carapace length (CL, to the nearest $0.1 \mathrm{~mm}$ ) was used as standard size for all specimens. It was decided to observe and measure shrimp of the same sex, females carrying eggs, as they are easily recognisable, and give a good representation of the general state of health of the population. The period and the place where sampling took place were similar every year. In all, 539 female shrimps were examined under a binocular microscope to detect the presence of deformities.

\subsection{Strategy to characterise deformities and relate them to environmental factors}

From November 2006 to November 2007, monthly campaigns to collect small mobile fauna (from the bottom and the surface) were carried out over a $60 \mathrm{~km}$ length of the Gironde estuary, included the $20 \mathrm{~km}$ area around the nuclear power plant (Fig 1). The protocol was the same as that used since the beginning of the 1980s. During these fishing campaigns, standard physico-chemical parameters were taken: temperature, salinity, conductivity and turbidity. Collected shrimp were preserved in $70 \%$ alcohol and sub-samples were prepared in the laboratory: about thirty individuals per station, per month and, where possible, per species were chosen at random. Each shrimp was then measured (CL, to the nearest $0.1 \mathrm{~mm}$ ), sexed, and weighed (Fresh weight, W, to the nearest $0.0001 \mathrm{~g}$ ). In all, 1,937 individual females, 3,145 males and 111 juveniles of $P$. longirostris were measured. A total of 2,235 $P$. macrodactylus were examined in a similar way (776 females, 694 males and 765 juveniles). The eggs from 247 ovigerous $P$. longirostris females were detached by immersing whole individuals in a 10\% bleach solution; the shrimp were then weighed (Fresh weight, W, to the nearest $0.0001 \mathrm{~g}$ ). The eggs in each clutch were counted and characterised according to stage of development: visible eye (stage II) or no visible eye (stage I). For P. macrodactylus, 89 clutches were weighed and the eggs counted.

\subsection{Observation of shrimp in experimental environment}

\subsubsection{Capturing the shrimps}

During February 2008, a batch of $P$. longirostris was caught using bow nets with mesh size 5 $\mathrm{mm}$, close to the port of Pauillac, about $80 \mathrm{~km}$ from the mouth of the Gironde estuary (Fig 1). Captured specimens were observed for damage to their body or appendages, and only undamaged shrimps (360, CL 6.0-16.6 mm) were selected for an experiment of 4 month 
duration. Half the individuals, which had no external visible morphological deformity, were the control. The other half had at least one deformity.

\subsubsection{Rearing conditions}

The shrimps were gradually acclimatised to the rearing conditions, which was different from their natural environment in terms of salinity (5 PSU), for about 3 hours. Fresh well water was used, maintained at a dissolved oxygen concentration of $10.3 \mathrm{mg} \mathrm{l}^{-1}$, $\mathrm{pH} 8.2$, and salted artificially at $15 \mathrm{PSU}$. Temperature was $15^{\circ} \mathrm{C}$ at the beginning of the rearing period and $20^{\circ} \mathrm{C}$ at the end, in accordance with the increase observed in the natural environment. Temperature fluctuations were avoided by the use of a thermoregulated chamber. These parameters were determined from a previous successful rearing of shrimps (Aurousseau, 1984). Before the beginning of the experiment, the shrimps were quarantined for 2 weeks, in order to select the least fragile individuals. Individual units were designed and built specially for this experiment (Fig 2). It was essential that all the shrimp were kept separate from each other, (i) to avoid problems of cannibalism that can frequently occur, (ii) to ensure that all individuals were fed identically, and (iii) to be able to monitor and recover the exuvia from each shrimp. The submerged units, consisting of a PVC pipe, $8 \mathrm{~cm}$ in diameter and $9 \mathrm{~cm}$ high, provided each shrimp with a vital volume of $453 \mathrm{~cm}^{3}$, sufficient to allow it to move around and to carry out the moulting processes. The submerged part had a $3 \mathrm{~mm}$ mesh which allowed good circulation of the water (oxygenation and waste removal). The units were grouped in batches of 6 and placed in 2 square tanks, $1.98 \mathrm{~m}$ x $1.95 \mathrm{~m}$. These two tanks formed a closed system, with the water circulating at a rate of $45 \mathrm{l} / \mathrm{min}$ though two sand filters and a $25 \mathrm{~W}$ UV filter. Every two days the shrimps were allowed to feed ad libitum on an artificial food (Biomar Ecostart no.1.9, composed of 56\% protein, $18 \%$ fats, $12.2 \%$ brute ash and $0.3 \%$ cellulose). The shrimps were kept in the dark throughout the entire experiment (except when being measured), as these conditions are similar to those found in the natural environment (the Gironde estuary is very turbid) and thus limited any stress related to captivity.

\subsubsection{Observations and measurements}

Every two days, when the shrimp were feeding, the following physico-chemical parameters were measured: temperature, oxygen, $\mathrm{pH}$, nitrates and nitrites. Each individual shrimp was also checked at this time. When a moult was observed, the shrimps underwent a series of measurements 2 days later, this delay was in order to give the new carapace time to harden (Nouvel-Van Rysselberge, 1937). The shrimps could then be manipulated without serious risk 
of causing trauma. For each shrimp, CL (to the nearest $0.1 \mathrm{~mm}$ ), W (to the nearest $0.0001 \mathrm{~g}$ ) and any deformities (location, size, persistence) were recorded. Photographs were also taken of some individual before and after each moult, to confirm the persistence of external deformities or the appearance of new ones. At the end of the experiment, or when a shrimp died, they were sexed (too difficult to carry out on live individuals without risk of causing trauma, as they are transparent) and dry weight was determined after oven drying $\left(48 \mathrm{~h}, 60^{\circ} \mathrm{C}\right)$.

\subsection{Statistical analyses}

All analyses were carried out using the $R$ software ( $R$ foundation core team, 2005). Percentages were compared using the $\mathrm{Chi}^{2}$ test. Links between the presence of deformities in the shrimp and environmental factors were explored using General Linear Models (GLM) (McCullagh and Nelder, 1989). A binomial error distribution via a logistic link function was applied. To obtain the relative importance of the variables (predictor), we assessed the residual deviance change after excluding each variable in turn from the total model. To evaluate the model, we used its percentage of variance explained (i.e. the difference between the Null model deviance and the residual model deviance, divided by the Null model deviance). ANCOVAs were used to evaluate differences between individuals with and without deformities in respect of size-weight ratio and size-number of eggs ratio in ovigerous females. Differences were considered as significant with a 95\% $(\mathrm{p}<0.05)$ confidence level.

\section{Results}

\subsection{Scale of the phenomenon since 1992}

Deformities in Palaemon species have been observed at least since 1992, the earliest year for which samples are preserved (Fig 3). The proportion of shrimps with at least one deformity is 58.8\% on average, but has varied between 30\% (1992) and 80\% (2000 and 2003). Variations from year to year are significant $\left(\mathrm{Chi}^{2}\right.$ test, $\left.\mathrm{p}>0.05, \mathrm{~N}=539\right)$ but no linear trend has so far been observed. From the samples, no link could be established between the proportion of deformed females and water temperature recorded during the fishing. However, there was a significant positive correlation with mean annual water temperature: the proportion of deformed females increased with temperature (GLM, binomial family, $\mathrm{p}>0.05$ ). There was no correlation with salinity.

3.2. Characterisation of deformities: analysis carried out on samples harvested during 20062007 and preserved in alcohol 


\subsubsection{Link with size, sex and environmental factors}

This analysis concerned a total of 5,193 P. longirostris individuals. Using a GLM (binomial family with a logit link), relationships were established between the presence of deformities and several factors: size of individual, sex, water temperature, salinity and turbidity. The response curve obtained described the probability of the shrimp presenting at least one deformity as a function of the combination of variables (Fig 4, a, b and c).

The model accounts for only $12.5 \%$ of the total variability observed, however some variables were significantly correlated with the presence of deformities. Size and sex accounted for the majority $(\mathrm{p}<0.05)$ : the probability of finding a shrimp with a deformity increased with size but differently according to sex (Fig 4-a). For example, a female shrimp with a cephalothorax length of about $10 \mathrm{~mm}$ has more than a $50 \%$ probability of having at least one deformity. The second factor which accounts for the presence of deformity is temperature, independently of other factors. The higher the temperature the greater the probability of finding a deformed shrimp (Fig 4-b). Salinity is the last factor to be linked significantly with the presence of deformity. The higher the salinity, the lower the probability of finding a deformed shrimp. For example, in fresh water, a female shrimp with a cephalothorax length of about $10.5 \mathrm{~mm}$ has a $60 \%$ risk of having a deformity compared with $50 \%$ in water at 25 PSU (Fig 4-c).

Turbidity was not linked significantly with the presence of deformity $(\mathrm{p}>0.1)$.

The same analysis carried out on the 2,235 $P$. macrodactylus shrimp gave similar results. The relationship between size, sex and the presence of deformity was therefore identical in both species.

\subsubsection{Size-weight relationship}

The relationship between shrimp fresh weight, patted dry (abbreviated to $\mathrm{W}$ in g) and length of cephalothorax (CL in $\mathrm{mm}$ ) was examined according to the presence or absence of a deformity, and sex of the shrimp. For $P$. longirostris, this relationship was weaker in shrimp with a deformity than without a deformity, for both sexes (ANCOVA, p<0.05) (Fig 5). Thus for shrimp of equal size, a deformed shrimp had a smaller weight than a non-deformed one, and this weight difference increased with size. The same difference was observed in $P$. macrodactylus males; for the females of this species, however, the difference was not significant. 


\subsubsection{Fecundity}

The relationship between the total number of eggs carried by each female and her size was not significantly different between deformed and non-deformed females for both species of shrimp (ANCOVA, $\mathrm{p}>0.1$ ). The developmental stage of the eggs spawned (I or II) did not affect the results. On the other hand, in the case of $P$. longirostris a difference was observed for the relationship between total weight of the clutch and size of the female: the deformed shrimp had a lighter clutch than the individuals with no deformity, whatever their size (ANCOVA, $\mathrm{p}<0.05$ ) (Fig 6). This difference was also seen in $P$. macrodactylus although it was not statistically significant (ANCOVA, $\mathrm{p}>0.5$ ).

\subsection{Observations monitoring live individuals for 4 months}

Ninety per cent of the shrimp monitored in this experiment were females with cephalothorax length of between 7.0 and $16.6 \mathrm{~mm}$ CL and fresh weight of between 0.194 and 2.380g. Males measured between 6.7 and $12.0 \mathrm{~mm} \mathrm{Cl}$ and weighed between 0.268 and $1.234 \mathrm{~g}$.

\subsubsection{Retaining deformities over several moults}

During the 130 days of monitoring, all individuals with a deformity retained the identical deformity in the course of successive moults (up to 7) (Fig 7). No further deformity was observed in any of these individuals. In shrimps with no deformity at the outset, no deformity appeared during the experimental period.

\subsubsection{Moulting frequency}

During the observation period, the majority of shrimp moulted between 3 and 4 times (minimum 1, maximum 7) (Table 1). Moulting frequency was examined using a GLM, with size or weight, sex and the presence of deformity being the 4 explanatory factors used. Size or weight accounted best for variations in the number of moults from one individual to another: the larger or heavier the individual, the fewer the moults. During the same period, the males moulted more often than the females (median 3 moults for the females, compared with 4 for the males). Shrimps with deformities moulted more frequently than those without: $25 \%$ of shrimps with deformities moulted 5 times or more compared with $16 \%$ of those without deformities (Table 1).

The inter-moult period (number of days between each moult) was examined in the same way. The males had a shorter average inter-moult than the females (median 21 days for the females 
and 20 days for the males) and this period increased with size. The inter-moult between the first and second moults was significantly shorter for shrimp with deformities, compared with shrimps without deformities (23.3 days on average for the deformed shrimp against 24.9 days for the non-deformed shrimps).

\subsubsection{Growth}

Growth rate in terms of size between the $1^{\text {st }}$ and $4^{\text {th }}$ moults was examined using a GLM, according to initial size, sex and the presence or not of deformities. Average growth rate was $6.5 \%$, varying from 0 to $55 \%$ according to the individual. It did not depend on sex, nor on the presence of deformities, but only on size (the larger the individual, the lower the growth rate). Growth in terms of weight increase was examined in the same way. The growth rate between the $1^{\text {st }}$ and $4^{\text {th }}$ moults was $6.5 \%$ on average, although some individuals lost weight and others gained considerable weight (up to 100\%). This rate did not depend on the presence of deformities, but on initial weight and sex: the females put on more weight than the males and larger individuals gained less weight.

The dry weight measurements were compared and there was no significant difference between individuals with deformities and those without. Dry weight represented about $20 \%$ of fresh weight.

\subsubsection{Mortality}

Mortality was zero until the $7^{\text {th }}$ week of the experiment (Fig 8). At the end of the observation period, cumulated mortality was $12.2 \%$ in the batch of shrimps without deformities (i.e. 22 individuals died out of 180 ) and $24.4 \%$ for those with deformities (i.e. 44 individuals out of 180). This is a significant difference $(\mathrm{p}<0.01)$ which does not depend on the size of the shrimp nor on their sex. It was also observed that these deaths usually occurred during the moulting process, or shortly afterwards.

\section{Discussion}

Analysis of the preserved samples of $P$. longirostris ovigerous females collected every year since 1992 revealed the persistence of this phenomenon over the course of several years, on a fairly large scale since, on average, more than $58.8 \%$ of the samples observed were affected. The proportions of individuals affected did vary significantly from year to year, which is explained in part by the positive correlation with temperature. 
For both species, $P$. longirostris and $P$. macrodactylus, the presence of exoskeletal deformities is related first of all by the size of the shrimp: the larger (i.e. older) the shrimp, the greater the probability of having at least one deformity. According to their growth curve (Béguer, unpublished data; Aurousseau, 1984), the difference between males and females can be explained simply by the difference in their size-age relationship. Two hypotheses can explain that fact: either the factor(s) causing the deformities is(are) accumulated throughout the shrimp's life, or the youngest individuals are less resistant and thus have a higher mortality rate, making way in the environment for the larger, and hence the less fragile individuals. Deformities could also be triggered by the sexual maturity, which is raised at a size of $8 \mathrm{~mm}$ CL for females (Béguer et al., in press). Contamination by pollutants (Rainbow, 1998; Ramade, 1992) or parasite infestation (Lauckner, 1984) may explain the first hypothesis. However, histological sections have been carried out and didn't show any parasite (Larrieu, 2008). No differences in heavy metal concentration were also found between deformed and normal shrimps (Larrieu, 2008), but concentrations into the hepatopancreas were fairly high. Further studies are needed in this area, and also on organic pollutants, or even on cocktails of pollutants that can act in synergy.

Independently of the size of the individual, the occurrence of deformities also depends on water temperature or on the season. It is difficult to separate these two factors: the month necessarily incorporates the temperature factor, but other parameters too, such as day length, rainfall, or even the presence of prey and predators. There is a peak in numbers of individuals with deformities in spring and in summer, when temperatures are highest. P. longirostris begins to reproduce at the end of winter and from the end of spring it enters a major growth phase (Aurousseau, 1984; Béguer et al., in press). After reproduction, the shrimps are weakened and must feed a great deal. One might think, therefore, that their accelerated metabolism during that period would favour the emergence of deformities. Temperature could also be a factor affecting the availability or the toxicity of the factor responsible for the deformities (Dimmock et al., 2004; Lemonnier et al., 2006). This seasonality could also be explained by fluctuations in pollutant input: in Gironde, spring and summer are the seasons when pesticides or other micropollutants are discharged and carried into the estuary by rivers and runoff water.

Salinity also proved to be an explanatory factor for the occurrence of deformities: individuals found in saline areas were less likely to have deformities than those in fresh water. Salinity is 
a factor that can affect the bioavailability of certain substances. Indeed, Pierron et al (2007) have shown that the higher the salinity, the lower the accumulation of cadmium by $P$. longirostris. This accumulation is also favoured by hypoxia. In the context of our study it was not possible to take into account oxygen levels in the environment as insufficient data were available (oxygen levels were not measured at each sampling station and there were difficulties in obtaining a representation of earlier conditions in a single reading).

It has been shown that in shrimp of the same size, individuals affected by at least one deformity have a lower weight than normal individuals, and this is true for both sexes of $P$. longirostris. This could be attributed to difficulties experienced by deformed shrimp in feeding in the natural environment. There could be mechanical problems, due possibly to a reduced ability to grasp their prey (hypertrophy of scaphocerites), or poor assimilation of food due to a physiological problem, or again due to the energy expenditure linked with trying to combat the factor responsible for these deformities (e.g. in the case of a detoxification mechanism). At the end of the 4-month rearing period, the weight of shrimps with deformities was still significantly lower than the weight of the control shrimp for identical size, even though they were fed in exactly the same way, both in quality and quantity. As it was not possible to check whether both categories of shrimp consumed the same food, the problem can come from food assimilation or extra energy expenditure. Nevertheless, we cannot ignore the fact that in the natural environment it is probably mechanically more difficult for a shrimp with a deformity to catch its prey.

The mass of eggs carried by females of $P$. longirostris without deformities was heavier than in specimens of equal size with deformities, thus may be indicating a decrease in the reproductive performance of the shrimps. This can have repercussions for the survival of the population. Analysis of the lipid composition of these spawns could be carried out to check whether there is a drop in egg quality and hence in the potentialities of their offspring.

Most of the results for the native $P$. longirostris are also valid for the exotic $P$. macrodactylus. However, in P. macrodactylus, the differences between individuals with deformities and those without (for weight and mass of eggs) were not always statistically significant. The reason may be that fewer data were available for this species, but also because of its different physiology or ecology. Indeed, P. macrodactylus lives further downstream, so in a more saline part of the estuary, and this, according to our results, seems to be less favourable for the 
emergence of the deformity phenomenon. Moreover, $P$. macrodactylus is an exotic species which settled here only fairly recently, and so the population is perhaps not yet affected to the same extent as $P$. longirostris.

Rearing a large number of shrimp in individual units, in a controlled environment for 4 months provided complementary data on the characteristics of deformities in living individuals and in particular helped demonstrate the negative impact of the deformities on the individuals that are affected. Overall mortality during our experiments was very low (zero during the first seven weeks), which shows that the rearing conditions during the 4 months were very good. Indeed, for P. longirostris, Aurousseau (1984) had a mortality of 50\% over 70 days, in similar salinity and temperature conditions.

Every one of the affected shrimp that were monitored retained their deformities during successive moults (up to 7). $P$. longirostris has a lifespan of 2 years maximum (Aurousseau, 1984; Van Den Brink and Van Der Velde, 1986), so although we are not able to assert that shrimp retain these deformities throughout their life, nevertheless we know that this is the case during a significant part of it. The hypothesis of a mutation at the level of the epidermal and/or germinal cells can therefore be envisaged. We also suggest that these deformities can be transmitted to their offspring; this would explain the persistence and the worsening of the phenomenon over several years. If larvae were hatched then monitored in a controlled environment this would show whether individuals were affected from their youngest stage of development.

No deformity appeared spontaneously in the control shrimp. This suggests that either these individuals were the most resistant and will never have the problem, or the conditions in the rearing environment prevented the phenomenon from occurring. However, no reversal was observed too. A rearing environment that incorporated several batches in various controlled environments could be planned to check the influence of physico-chimical parameters on the appearance of the deformities.

We have shown that moulting frequency is significantly higher in shrimp with deformities than in those without, which would indicate a different metabolism in the two categories of shrimp. Although indispensable, the moulting process is nevertheless not without some risk for the life of the shrimp (Drach, 1939). During our experiment we observed that all the shrimp that died did so during the moulting process or soon after. This may therefore explain the significantly higher mortality rate (double) in the shrimp with deformities compared to the controls. During the monitoring period, shrimp with deformities and those without were kept 
in the same conditions, thus the deformities are the only explanatory factor for the difference observed in mortality. As moulting frequency is accelerated by the increase of temperature (Barclay, 1978; Campillo, 1979; Nouvel-Van Rysselberge, 1937), deformed shrimps should have a higher mortality rate than non deformed ones particularly in summer.

We present a diagram summarising the consequences observed and the possible links and action/functioning of the factors responsible for the deformities (FRD) (Fig 9). The FRD could be permanently present in the environment, acting on the shrimp throughout their lifespan, on all developmental stages. This could explain why in the natural environment we found a big proportion of deformed shrimps although a higher mortality rate was demonstrated in our experiment. The FRD could then be accumulated during the shrimp growth and cause a general physical weakening. The shrimps with deformities would then have offspring of inferior quality, a higher frequency of moult and then a higher level of mortality than those without deformities. The first stage could be affected directly by the FRD, including during the egg stage, or though a parental transmission (genetic or metabolic). The action of the FRD could be influenced directly or indirectly by environmental parameters: increased effects as temperature increases, and on the contrary, inactivity of the effects in very high levels of salinity. Finally, the big proportion of deformed shrimps and the individual effects associated could have serious consequences on population viability.

The next step is now to look for the possible causes of these deformities in order to evaluate the possibility of reducing or eliminating it, the possibility of using shrimps as a bio-indicator species, and to detect probable effects on other inhabitants of the estuary.

\section{Acknowledgements}

The authors would like to thank Bernard Ballion, Romaric Le Barh, Jean-François Bigot, Gérard Castelnaud, Christine Gazeau, Aymeric Guibert, Philippe Jatteau, Mario Lepage and everyone who took part in the sampling process. Grateful thanks also to all the staff at the StSeurin station where the shrimp were reared. Thanks also to Aude Lochet and Hilary Koziol for language help. This study was financed by the CNPE du Blayais and the Aquitaine Regional Council. 


\section{References}

Aguirre, H., Hendrickx, M.E. 2005. Abnormal rostrum and telson in two species of penaeid shrimp (Decapoda, Dendrobranchiata, Penaeidae) from the Pacific Coast of Mexico. Crustaceana. 78, 113-119.

Aurousseau, J.-M. 1984. Eléments d'écologie de la crevette blanche, Palaemon longirostris, dans l'estuaire de la Gironde. Dynamique de la population et production. Thèse de doctorat. Biologie Animale mention Ecologie, Paris.

Barclay, W. 1978. Development of spawning and mass larva-rearing techniques for the euryhaline shrimp Palaemon macrodactylus, in: Knight, A.W. (Ed) Studies on Bioenergetics, Osmoregulation, Development, Behavior, and Survival of Several Aquaculture Organisms. Dep. Land. Air and Water resources, Water Sci and Eng. Paper N4507, University of California, Davis, Davis, California, pp. 137-143.

Béguer, M., Bergé, J., Girardin, M., Boët, P. in press. Reproductive biology of Palaemon longirostris (Palaemonidae): Comparison of the Gironde estuary population with European ones. Journal of Crustacean Biology. 30(2) DOI: 10.1651/09-3153.1,

Béguer, M., Girardin, M., Boët, P. 2007. First record of the invasive oriental shrimp Palaemon macrodactylus Rathbun, 1902 in France (Gironde estuary). Aquatic Invasions. 2, 132-136.

Béguer, M., Pasquaud, S., Boët, C., Noël, P., Girardin, M. 2008. First description of main skeletal deformations in shrimps populations of the Gironde estuary (France). Hydrobiologia. 607, 225-229.

Campbell, P.J., Jones, M.B. 1989. Osmoregulation of the estuarine prawn Palaemon longirostris (Caridea: Palaemonidae). Journal of the Marine Biological Association of the United Kingdom. 69, 261-272.

Campillo, A. 1979. Contribution à l'étude de la crevette rose Palaemon serratus (Pennant) : Exploitation, Biologie, Elevage, Epidémiologie. Thèse de Doctorat

De Grave, S., Mentlak, T. 2008. A Record of an Unusual Rostrum in Palaemon Longirostris H. Milne Edwards (Decapoda, Palaemonidae). Crustaceana. 81, 1403-1406.

Delphy, J. 1921. Pinces anormales de crabes. Bulletin de la Societe Zoologique de France. 46, 156-157.

Dimmock, A., Williamson, I., Mather, P.B. 2004. The influence of environment on the morphology of Macrobrachium australiense (Decapoda: Palaemonidae). Aquaculture International. 12, 435-456.

Drach, P. 1939. Mue et cycle d'intermue chez les Crustacés Décapodes. Annales de l'Institut Oceanographique. 19, 103-391.

Dutt, S., Ravindranath, K. 1974. Notes on abnormal shrimps and prawns. Current Science. 43, 684-685.

Girardin, M., Castelnaud, G., Laplaud, A., Gonthier, P. 2008. Surveillance halieutique de l'estuaire de la Gironde - suivi des captures 2006-2007 - étude de la faune circulante 2007

Gonzalez-Ortegon, E., Cuesta, J.A. 2006. An illustrated key to species of Palaemon and Palaemonetes (Crustacea: Decapoda: Caridea) from European waters, including the alien species Palaemon macrodactylus. Journal of the Marine Biological Association of the United Kingdom. 86, 93-102.

Gurney, R. 1923. Some notes on Leander longirostris M. Edwards, and others British prawns. Proceedings of the Zoological Society of London. VII, 97-123. 
Holthuis, L.B. 1980. FAO Species Catalogue. Vol 1: Shrimps and Prawns of the World - An annoted Catalogue of Species of Interest to Fisheries, FAO Fisheries Synopsis, Rome.

Larrieu, M. 2008. Déformations exosquelettiques chez les crevettes $P$. longirostris et P.macrodactylus: les contaminants métalliques sont- ils responsables? Mémoire de Master II

Lauckner, G. 1984. Impact of trematode parasitism on the fauna of a North Sea tidal flat. Helgoländer Meeresuntersuchungen. 37, 185-199.

Lemonnier, H., Herbland, A., Salery, L., Soulard, B. 2006. "Summer syndrome" in Litopenaeus stylirostris grow out ponds in New Caledonia: Zootechnical and environmental factors. Aquaculture. 261, 1039-1047.

McCullagh, P., Nelder, J.A. 1989. Generalized linear models, Chapman and Hall, Londres.

Nouvel-Van Rysselberge, L. 1937. Contribution à l'étude de la mue, de la croissance et de la régénération chez les Crustacés Natantia. Rec. Inst. Zool. Torley-Rousseau. 6, 5-161.

Pasquaud, S. 2006. Les relations trophiques : éléments de structuration des peuplements ichtyologiques en milieu estuarien - Application à l'estuaire de la Gironde. Thèse de doctorat. Cemagref, Bordeaux.

Pasquaud, S., Elie, P., Jeantet, C., Billy, I., Martinez, P., Girardin, M. 2008. A preliminary investigation of the fish food web in the Gironde estuary, France, using dietary and stable isotope analyses. Estuarine Coastal and Shelf Science. 78, 267-279.

Pierron, F., Baudrimont, M., Boudou, A., Massabuau, J.C. 2007. Effects of salinity and hypoxia on cadmium bioaccumulation in the shrimp Palaemon longirostris. Environmental Toxicology and Chemistry. 26, 1010-1017.

R foundation core team 2005. R: A Language and Environment for Statistical Computing. R Foundation for Statistical Computing, Vienna, Austria

Rainbow, P.S. 1998. Phylogeny of trace metal accumulation in crustaceans, in: Langston, W.J., Bebianno, M. (Eds) Metal Metabolism in Aquatic Environments. Chapman \& Hall, London, pp. 285-319.

Ramade, F. 1992. Précis d'écotoxicologie, Masson, Paris.

Sitts, R.M., Knight, A.W. 1979. Predation by the estuarine shrimps Crangon franciscorum Stimpson and Palaemon macrodactylus Rathburn. Biological Bulletin. Marine Biological Laboratory, Woods Hole. 156, 356-368.

Sorbe, J.C. 1983. Les Décapodes Natantia de l'estuaire de la Gironde (France). Contribution à l'étude morphologique et biologique de Palaemon longirostris H. Milne Edwards, 1837. Crustaceana. 44, 251-270.

Van Den Brink, F.W.B., Van Der Velde, G. 1986. Observation on the population dynamics and distribution of the White Prawn Palaemon longirostris H. Milne Edwards, 1837 Crustacea Decapoda Natantia) in the Netherlands, with special reference to its occurrence in the major rivers. Archiv für Hydrobiologie. 107, 465- 495. 


\section{List of figures}

Table 1: Moulting frequency during the experimental rearing study (4 month) of $P$. longirostris adults.

Fig 1. The sampling stations in the Gironde estuary.

Fig 2. Individual units built specially for the experiment.

Fig 3. Proportion of deformed ovigerous shrimps P. longirostris since 1992, in samples from the Gironde estuary collected during the spring (numbers in bars are the number of shrimps observed).

Fig 4. Predicted values from the GLMs: mean probability for a shrimp ( $P$. longirostris) to be affected by a deformity according to its size and sex (A), the water temperature (B, example for females of different sizes) and the salinity (C, examples for females for different sizes).

Fig 5. Relationship between weight and cephalothorax length (CL) according to the sex and the presence of deformities for the shrimp $P$. longirostris (Deformed females : $\mathrm{W}=0,0017 \mathrm{Cl} 2,60 \mathrm{r}^{2}=0.86$, $\mathrm{p}<0.001$ : Not deformed females $\mathrm{W}=0.0012 \times \mathrm{CL}^{2.78}, \mathrm{r}^{2}=0.94, \mathrm{p}<0.001$; Deformed males $\mathrm{W}=0.0019(\mathrm{CL})+2.52 \mathrm{r}^{2}=0,78 \mathrm{p}<0.001$; Not deformed Males $\left.\mathrm{W}=0.0013 \times \mathrm{CL}^{2.73}, \mathrm{r}^{2}=0,90, \mathrm{p}<0.001\right)$.

Fig 6. Relationship between clutch weight (CW) and female size (CL), for $P$. longirostris deformed and not deformed. (Deformed : $\mathrm{CW}=(0.0245 \times \mathrm{CL})-0.1537\left(\mathrm{r}^{2}=0.42, \mathrm{p}<0.001\right)$; Not deformed : $\mathrm{CW}=(0.00355 \times \mathrm{CL})-0.250\left(\mathrm{r}^{2}=0.56, \mathrm{p}<0.001\right)$.)

Fig 7. Retained deformities in P. longirostris after moulting (C: Cephalothorax with a bump form; R: Rostrum curved downwards; the dashed line is the position of a normal rostrum)

Fig 8. Accumulated mortality of deformed and not deformed P. longirostris (week n¹9: 44 deformed shrimps dead (136 deformed shrimps alive) and 22 non-deformed dead (158 non-deformed shrimps alive).

Fig 9. Diagram outlining the process of deformities in shrimps according to our study (full arrow) and hypothesis about the direct action or indirect action of the factor(s) responsible for such phenomenon (dotted arrow) 
Table 1 : Moulting frequency during the experimental survey (4 month) of $P$. longirostris adults

\begin{tabular}{cccc}
\hline $\begin{array}{c}\text { Number of moults per } \\
\text { shrimp during } \\
\text { experimental time }(4 \\
\text { month) }\end{array}$ & $\begin{array}{c}\text { Proportion of } \\
\text { deformed } \\
\text { individuals } \\
(\%)\end{array}$ & $\begin{array}{c}\text { Proportion of } \\
\text { non-deformed } \\
\text { individuals } \\
(\%)\end{array}$ & $\begin{array}{c}\text { Total number } \\
\text { of individuals }\end{array}$ \\
1 moult & 9 & 10 & 33 \\
2 moults & 14 & 20 & 61 \\
3 moults & 29 & 32 & 109 \\
4 moults & 23 & 22 & 80 \\
5 moults & 17 & 12 & 52 \\
6 moults & 6 & 3 & 15 \\
7 moults & 2 & 1 & 5 \\
\hline
\end{tabular}


Fig. 1

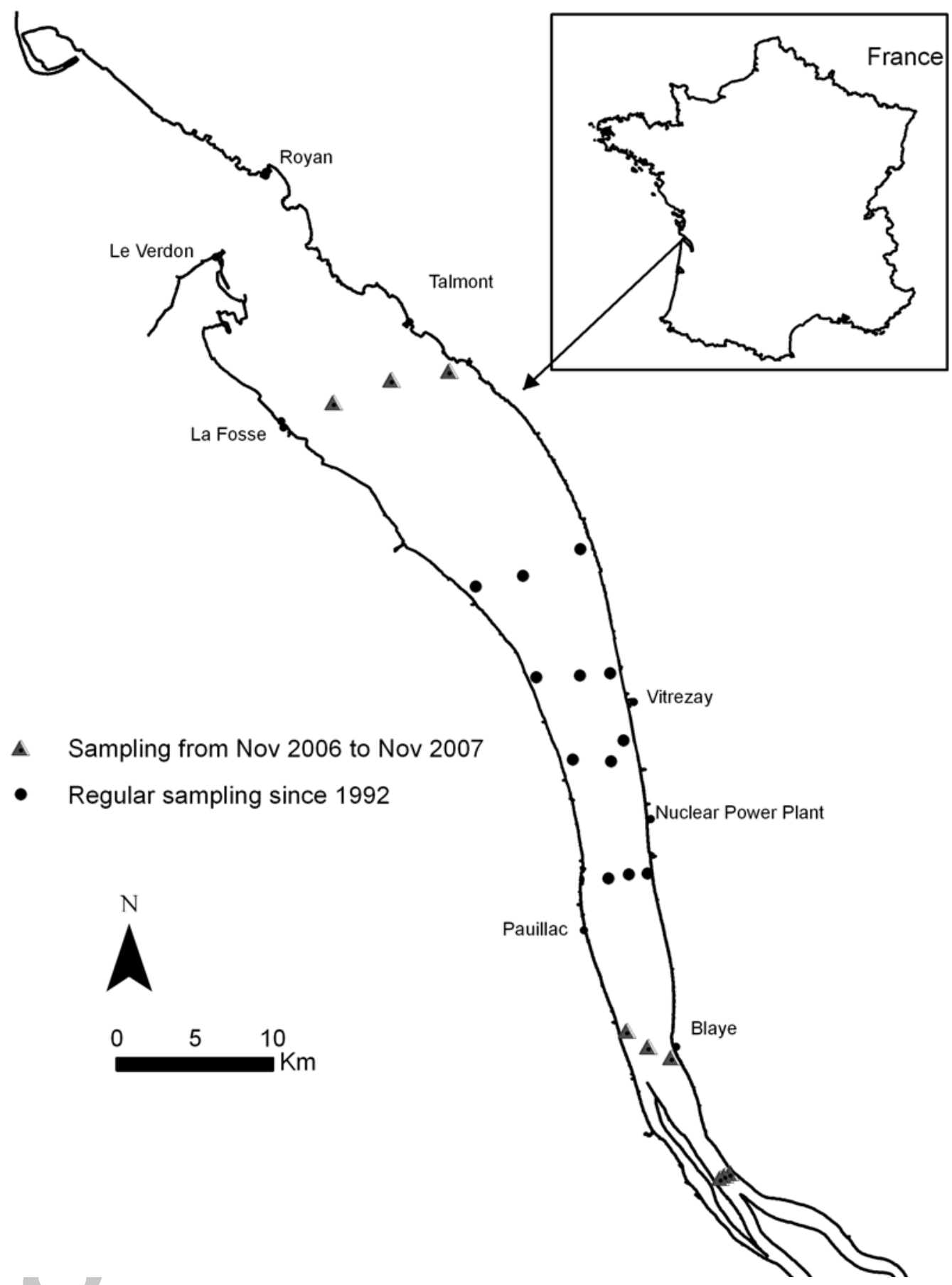


Fig. 2

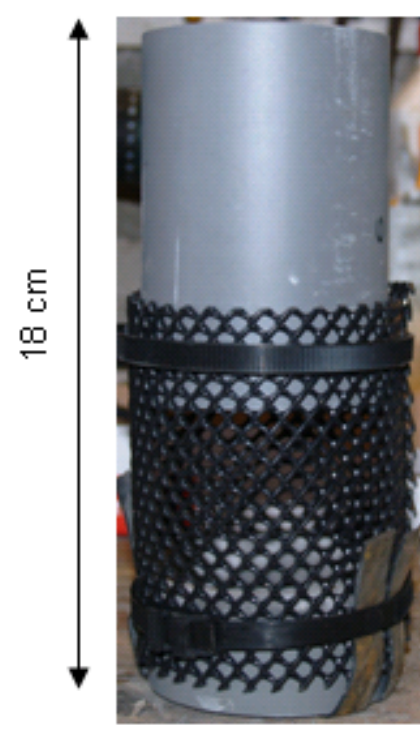

$8 \mathrm{~cm}$

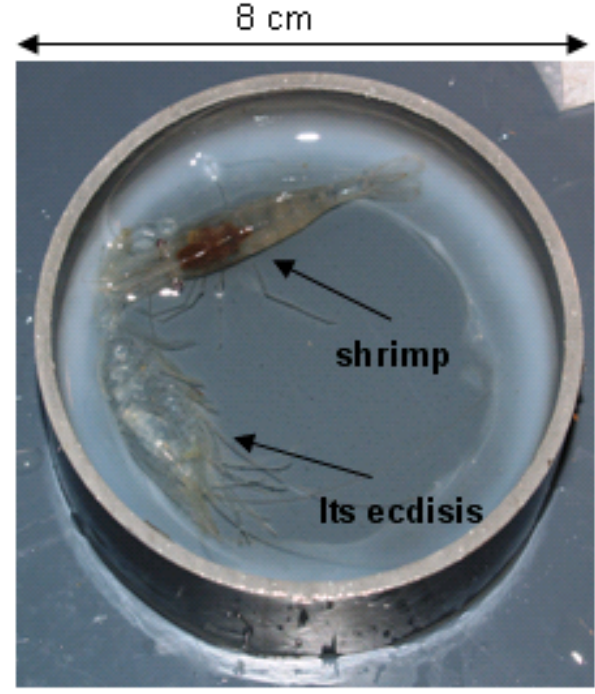

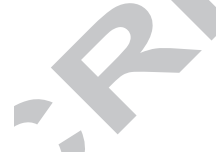




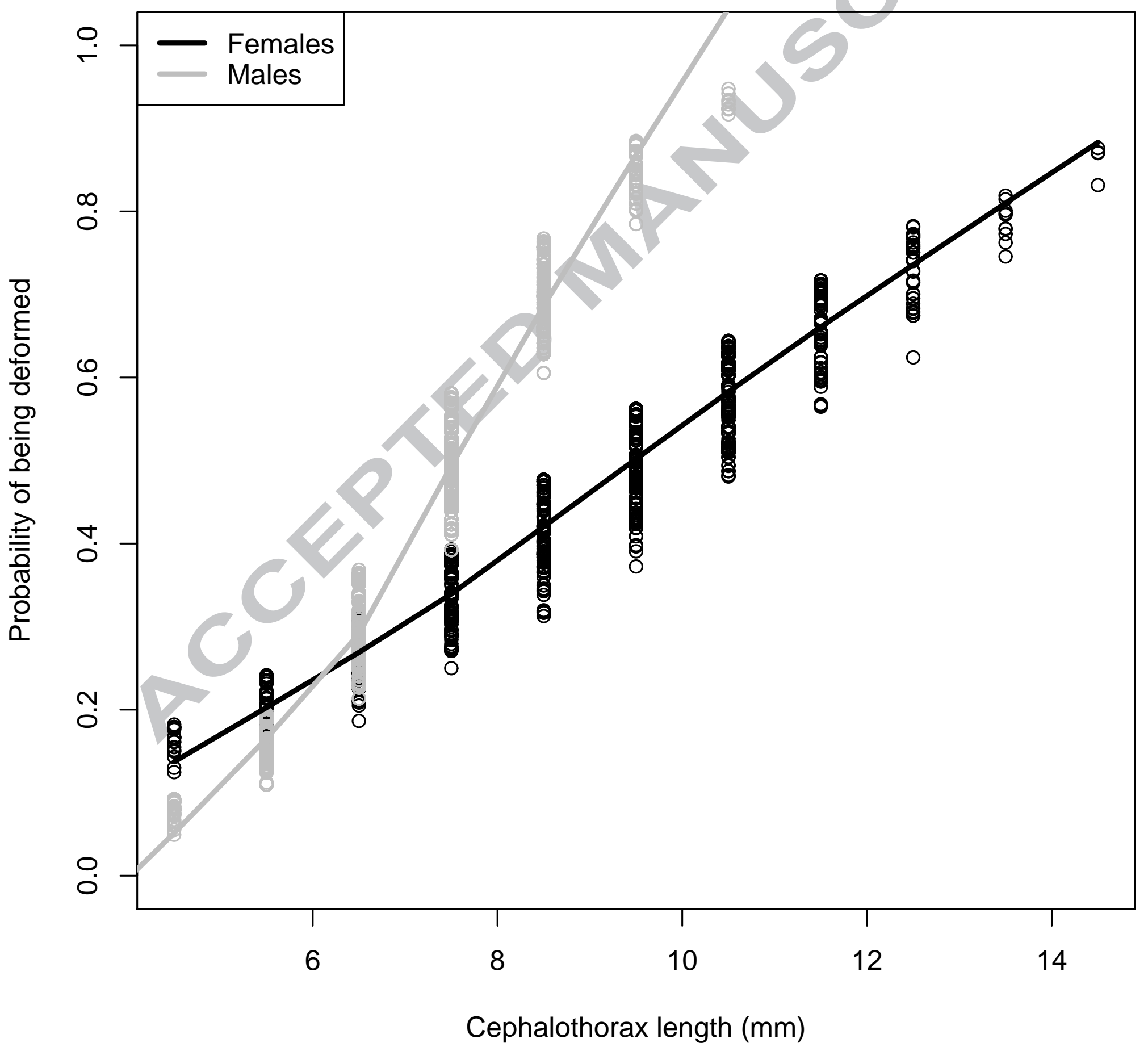




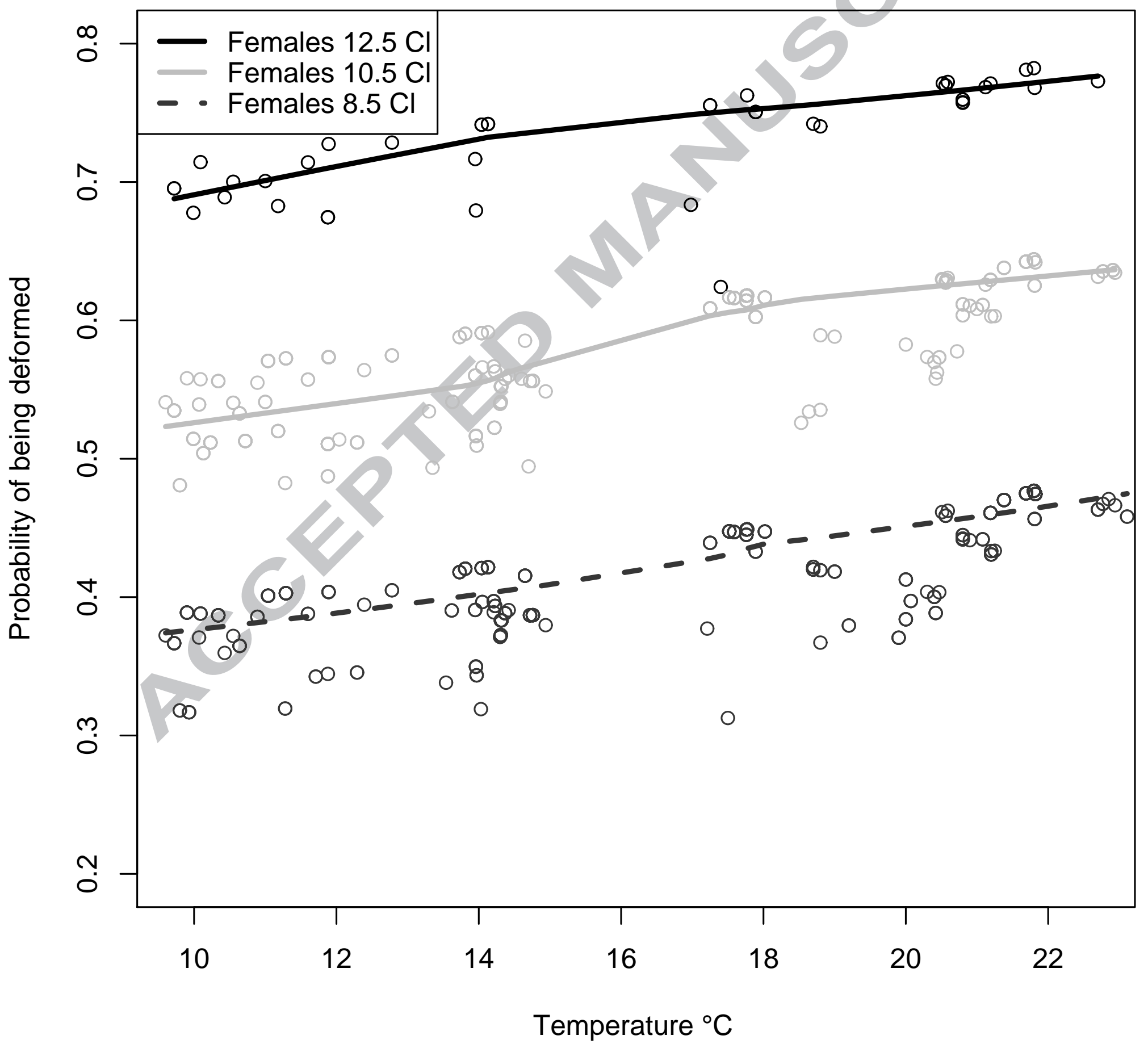




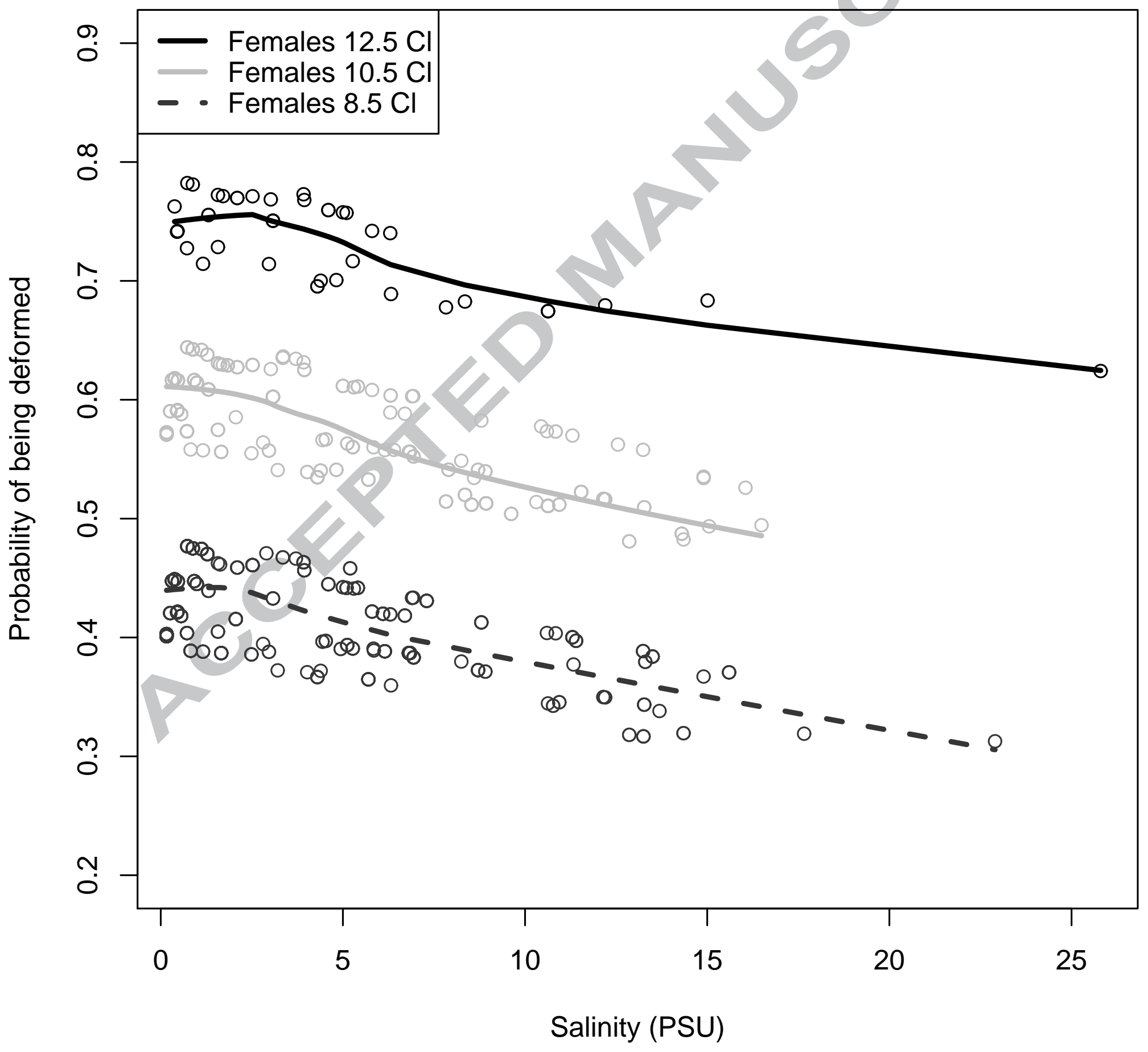




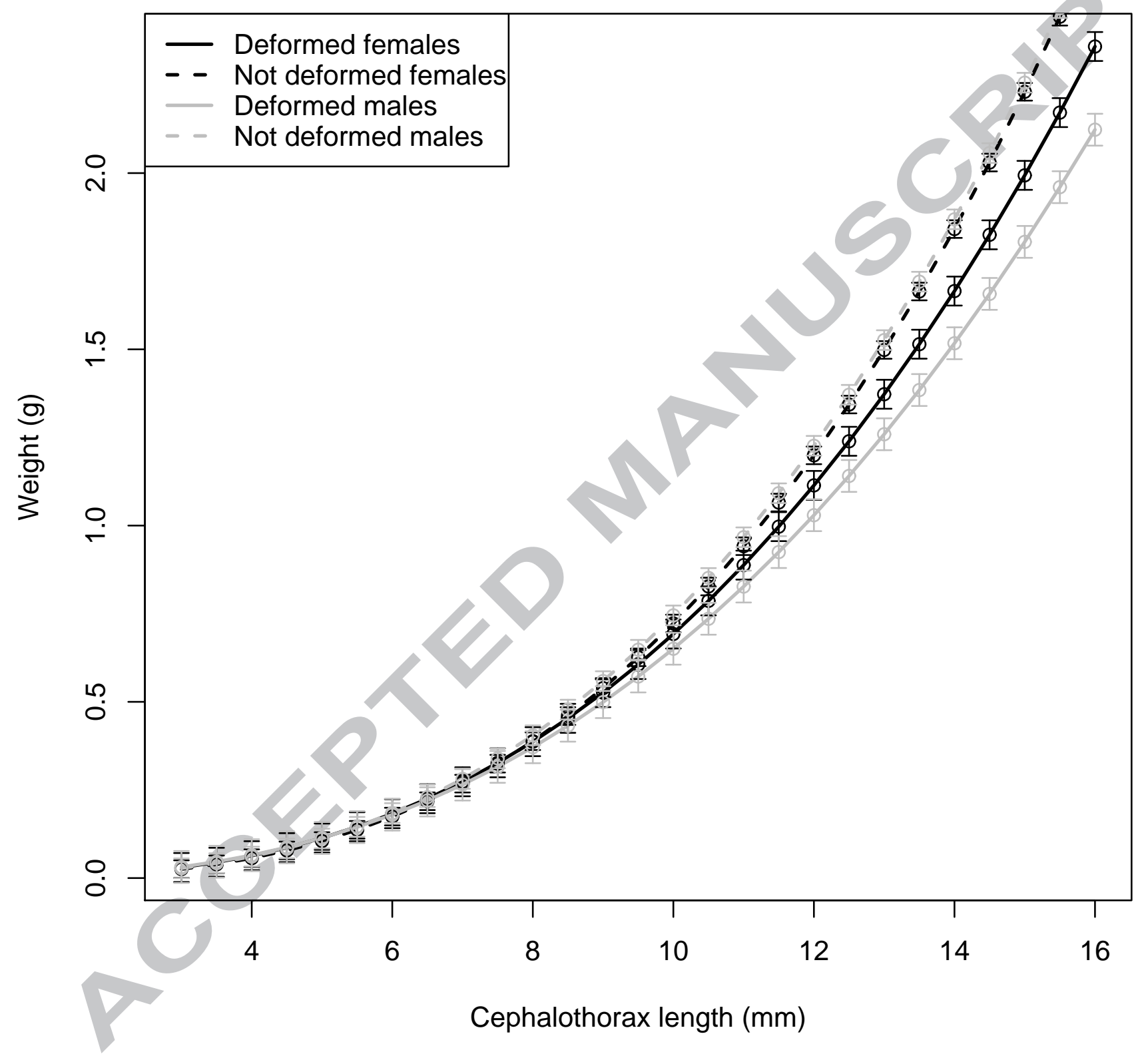




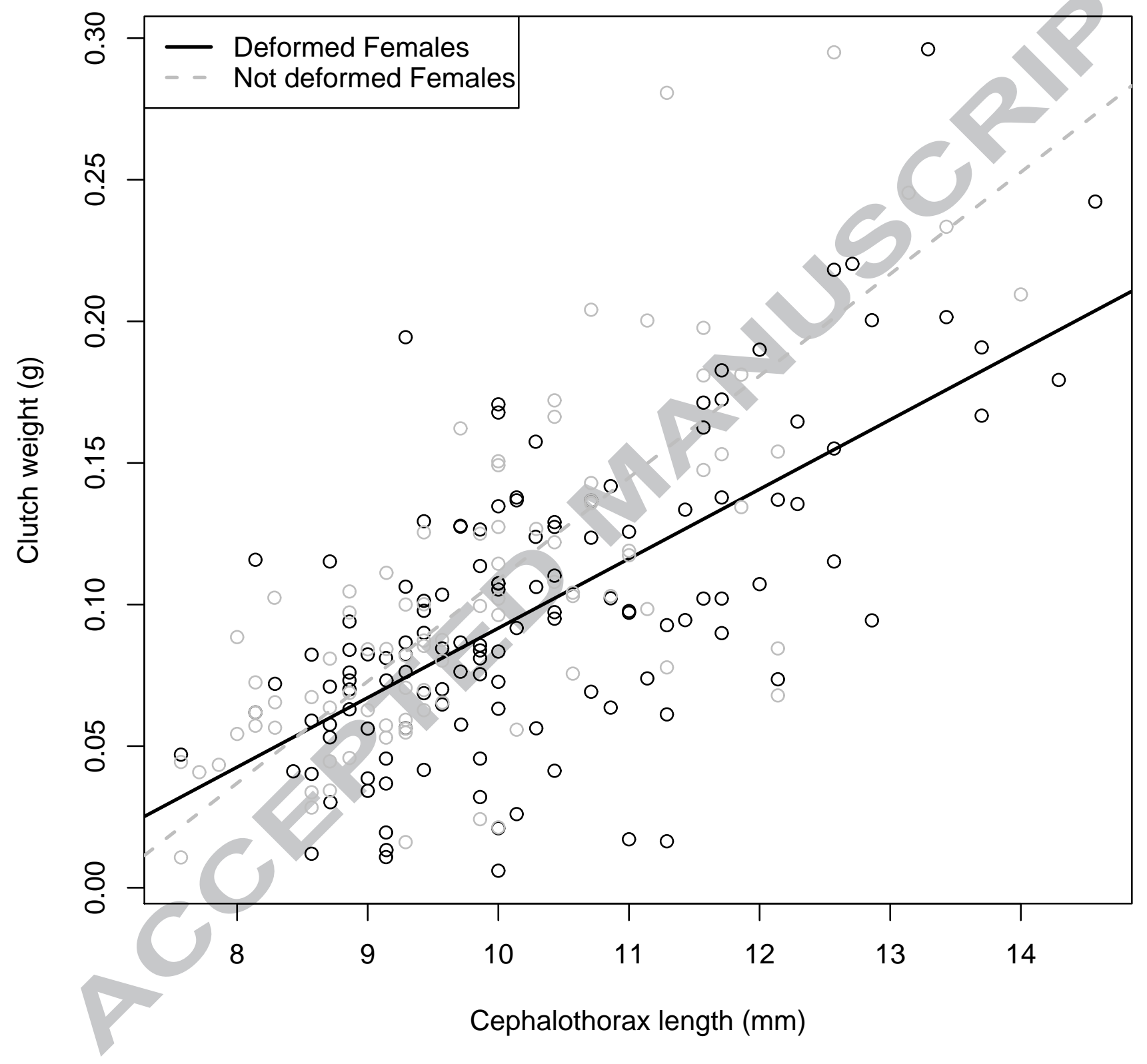


Fig. 7

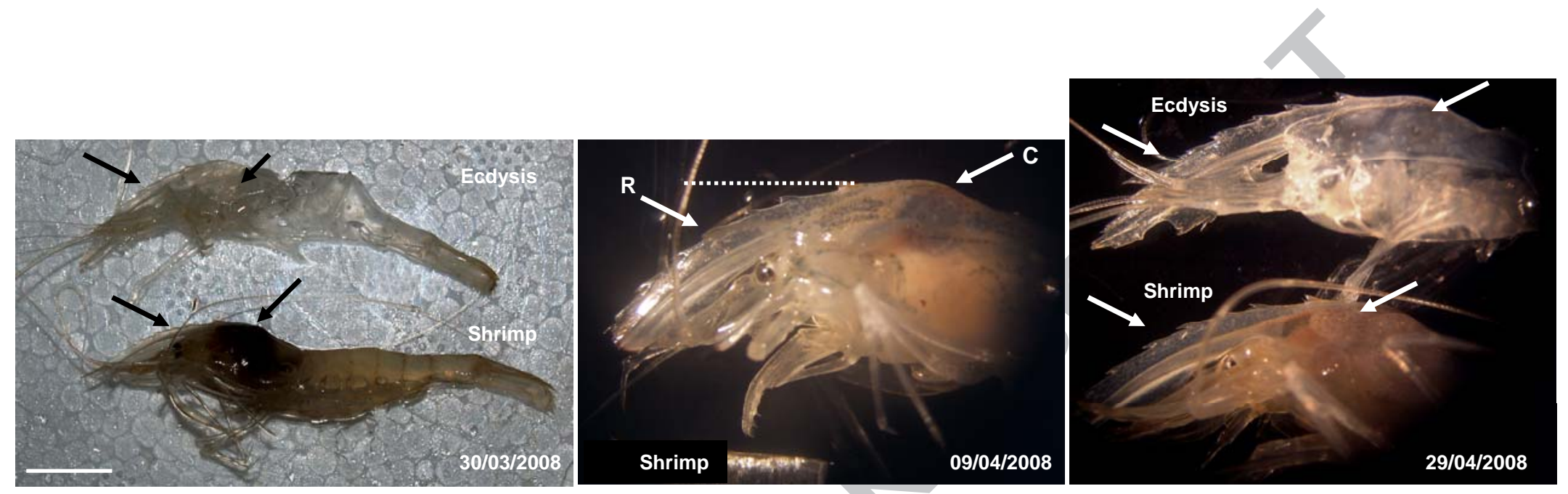


Fig. 9.

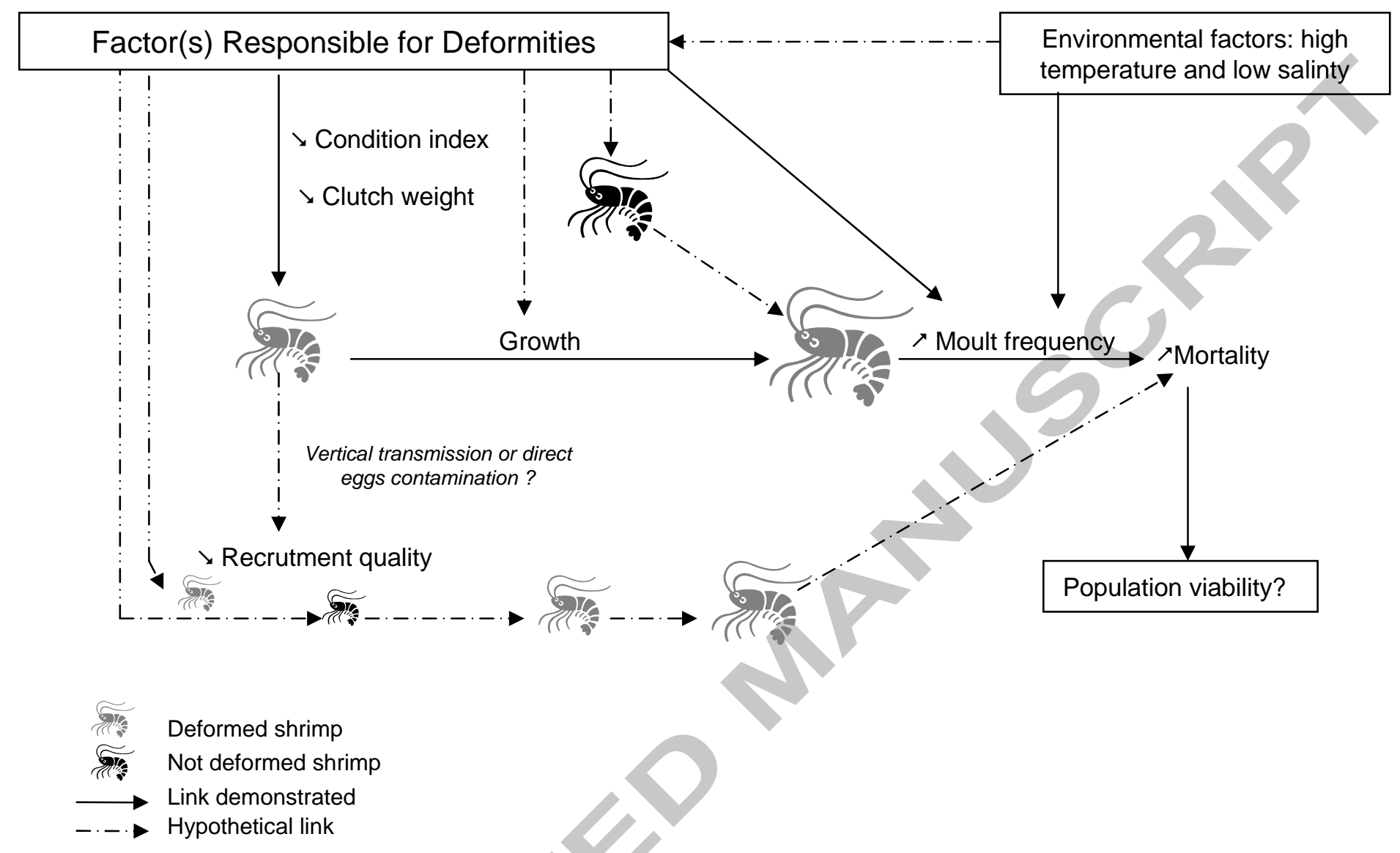


Fig. 8

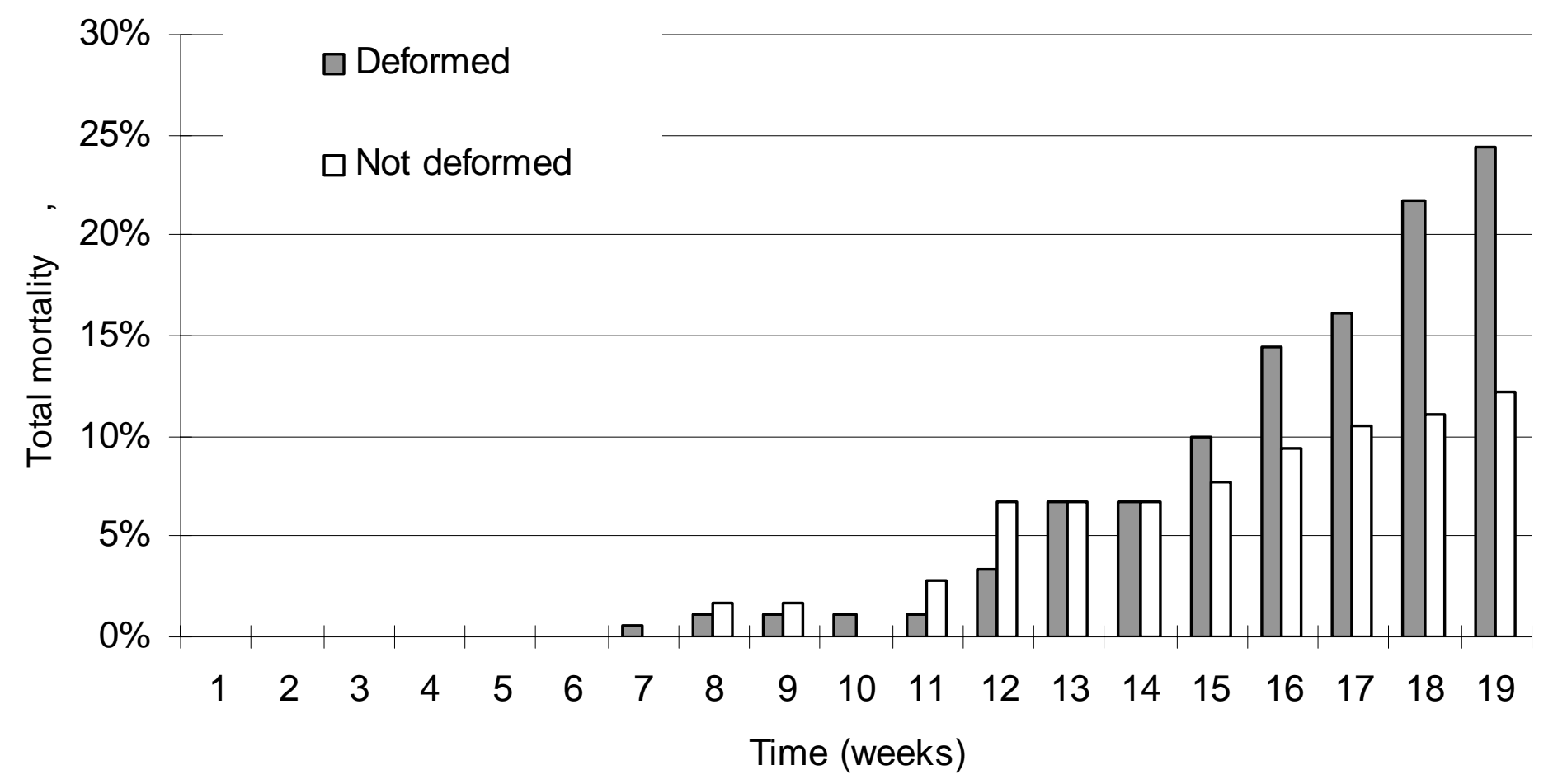

